\title{
Democratic Principle and the Right to Decide: The Case of Catalan Secession
}

\author{
José J. Jiménez Sánchez \\ Universidad de Granada, Granada, Spain \\ Email: jimenezs@ugr.es
}

Received 6 July 2014; revised 12 August 2014; accepted 15 September 2014

Copyright (C) 2014 by author and OALib.

This work is licensed under the Creative Commons Attribution International License (CC BY). http://creativecommons.org/licenses/by/4.0/

\section{c) (i) Open Access}

\begin{abstract}
These pages reflect on the connection, at first sight evident, between the democratic principle and the right to decide. However, this work highlights some of the contradictions in which certain of its supporters fall and it defends. On the contrary, the need to establish that the relationship between the principle of the rule of law and the democratic principle cannot give either preeminence over the other. The reason lies in that the democratic principle cannot be understood as the mere sum of particular wills of a specific community, but rather as an expression of the conditions that ensure the formation of a rational political will. The democratic principle can only be understood from a normative, and not factual, conception of sovereign power.
\end{abstract}

\section{Keywords}

\section{Democracy, Right to Decide, Sovereign Power}

Subject Areas: Law, Politics

\section{Introduction}

Stevenson's text is both right and wrong. The text is correct in so far as it follows the idea that freedom requires full independence, even though it is wrong in interpreting that this independence is only certain with death. By doing so it avoids confronting the decisive problem, which consists in knowing how a contingent world achieves the required independence for freedom. Something similar happens in the debate on the right to decide in which Spain finds itself today, a debate that correctly connects the right to decide with the democratic principle, but errs when addressing the decisive issue, that is, what we are to understand by the democratic principle.

Although all agree that democracy must be understood as government of the people, it is certain that a difference would be established as to how we should think of that government. Many authors identify the democratic principle with the political will of a specific people or a section of the population with certain characteristics [1], that is, democracy would not only consist of what that political will could express, but in accepting what such 
will would manifest. No one would put any objection to that will, as this would be legitimized to the extent that it is the opinion of the majority, either of a specific people or from a particular group. In this way the will of a political majority is intertwined with the democratic principle. This principle would define the desire of the will of the political majority as legitimate.

If we accept that democracy is understood as a majoritarian democracy in which the political will that has to prevail is one that can be identified with the will of the majority, there is no choice but to recognize that: Firstly, the means which are none other than the legal means have to be facilitated, so that the political will can be expressed; secondly, this will cannot be left simply as mere expression, because to the extent it demands to go further, it has to be able to exercise the right to decide. That is, it must be able to make a decision; and thirdly, the adoption of a decision requires the execution of essential measures needed to carry it out. In short, the democratic principle necessarily demands that the indispensable steps are taken for the implementation of what the will of the political majority wants.

However, this democratic principle requires us not only to attend to the will of a specific people, but to every political will that acquires a certain density, that is, that actually it must have some entity and therefore can be constituted with its own identity, distinct from all others. This is the case of Catalonia, in which after the events that have occurred, seems to constitute a majoritarian political will that wants to express its desire to determine its political future. Thus the democratic principle demands that we affirm the legitimacy of such a claim, although that will not prevent us from confronting a range of extremely complex issues, for in turning the Catalan people's aspiration into reality it would have to be made compatible with the existing law, that is, we would have to achieve a coherent articulation between the democratic principle and the principle of the rule of law. Hence, we should have to resolve both internal problems, those relating to whether to hold a referendum or a consultation with all the legal problems that that may involve [2], and also external ones, relating to the consequences that could result from the constitution of a new state, especially in an area such as the European Union [3].

\section{Resolution 5/X of the Catalan Parliament of 23 January, 2013}

This Resolution makes a declaration of sovereignty and defends the right of the people of Catalonia to decide. Regarding the first, it states that the "people of Catalonia has, for reasons of democratic legitimacy, the character of a legal and political sovereign subject". This statement raises two types of problems, which relate both to the definition of the people as sovereign, and to the reasons for its justification. I shall start by trying to clarify the latter, because in principle it is not clear what is meant by the phrase "for reasons of democratic legitimacy", since it could be understood either as what the majoritarian will of the people has decided, that is, democracy is understood as government of the majoritarian will of the people, or what that same will has agreed under certain conditions, so that democracy cannot simply be identified with the will of the majority, but would be subject to certain requirements.

In the introduction to that statement it is said to be formulated "[i] $\mathrm{n}$ accordance with the democratically expressed majoritarian will of the people of Catalonia". While this statement does not allow us to clarify what we might understand by "reasons of democratic legitimacy", at least it enables us to rule out something that fits under that expression, that is, that democratic legitimacy cannot simply be identified as the manifestation of the majoritarian will of the people, since it would only be legitimate if its formulation was a democratic expression, which would refer to the need for certain conditions to ensure that the will did so, that it was expressed democratically, although it would not be possible to obtain more from that statement.

The Resolution also defends the right to decide, in relation to which it makes two clarifications, which can help us to understand what is meant by democratic legitimacy. First, such a right must be exercised "using" the existing legal frameworks, so that "democratic strengthening" is achieved, from which it follows that respect for legality is essential in a democracy that can be considered as legitimate. And, in the second place, it states that the right to decide will only be democratic if it guarantees plurality and respect for different options, so as to ensure dialogue and deliberation. Only thus can the democratic legitimacy of the majoritarian will be assured.

Therefore, the answer we found to the difficulties posed above when we asked what we could understand by "reasons of democratic legitimacy" is a complex one, with the result that we cannot simply identify the expression of the majoritarian political will as the democratic expression of that same will, since it will only be democratic if in its shape and expression it fulfils a number of conditions that will grant it the democratic character, 
that is, its democratic legitimacy. These conditions are twofold: first, the majoritarian political will be democratic if it is exercised within the legal framework, that is, the democratic principle is necessarily intertwined with the principle of the rule of law, and secondly, it is not enough that the majoritarian democratic will respects legality, but democratic legitimacy also requires the political will to be based on grounds that go beyond a specific normative framework. This is why it is necessary for the majoritarian political will to be articulated around the defence of the requirements demanded for its implementation in a specific society of what might be called the principle of discourse, that is, the defence of plurality, respect for different options and ensuring common deliberation. In short, majority rule, that is to say, a majoritarian political will, can only be justified if it complies with the democratic principle, which would, in turn, articulate two principles, the rule of law and discourse. Habermas had formulated this, saying that a democratic rule of law would be reached when the discourse principle is transformed in a principle of democracy "in assuming a legal shape" [4].

If the Resolution could be seen in this way, there would be no objection. However, this Resolution does not argue only for what I have just said, but also affirms, as we saw above, something more, namely, the character of a legal and political sovereign subject, which was justified "for reasons of democratic legitimacy". Actually we know that no matter what is said, what are relevant are the grounds on which what is said is based. If this is so, we should have to look at the reasons that support this assertion of sovereignty, that is, the democratic reasons, and if as we said, the democratic principle is intertwined with other principles such as discourse and the rule of law, it seems clear that based on that we cannot go beyond this last, for it would be contradictory to say one thing and its opposite at the same time. That is, if democracy is upheld by legality, something that goes beyond that legality cannot be defended, and yet say at the same time that it is democratic. This is the problem of the Resolution, which defends both one thing and its opposite when it states that the Catalan people has the character of a legal and political sovereign subject for democratic reasons when those reasons necessarily lead us to uphold the rule of law, from which to argue precisely the opposite claim, namely, that sovereignty resides, according to the Constitution, in the Spanish people as a whole.

\section{Report [5] of the Instituto de Estudios Autonómicos}

This Report starts from Resolution 5/X of the Catalan Parliament which defends, as we have seen, the Catalan people's right to decide and, consequently, their right to be consulted. However, the argument of the Report differs from that followed in the Resolution. The reason seems obvious, as it tries to avoid the contradiction into which the Resolution falls by defending the democratic principle and legality at the same time as it defends the illegality of the creation of a new legal and political subject. To undo that contradiction, while still maintaining the new sovereign, it is essential to understand the democratic principle differently. In the Resolution that democratic principle was designed in such a way that it was intertwined, especially in what concerns us now, with the principle of the rule of law, so that it was impossible to understand one without the other, leading us to what might be called a legalized democracy. Therefore, the Report will understand, now, that the democratic principle is not only separate from the principle of the rule of law, but rather will conceive the latter so that it is subordinate to the former, that is, the principle of the rule of law has to be relegated to the primacy of the democratic principle. In this, the Report is not at all original nor does it do anything different from what many authors have done, some of them mentioned in the introduction to this text, who have defended it in Spain. Moreover, it merely follows a centuries-old tradition that conceives of political power in factual terms, that is, it thinks the political will is primordial as against the law, leaving this latter subordinate to the former. The difficulty it then has to face would be that this tradition is neither the only nor the most consistent nor the best articulated, at least from a rational standpoint, which is the point of view that we are required to adopt, as it is from there, rationality, where we could ensure a common ground which would resolve our differences in a civilized manner.

However, all these problems are not the immediate objective of the Report, even though they are its background. The Report attempts to answer the question that the Resolution would have posed when it recognized the right to decide, as one would expect of a people who had been endowed with the character of a legal and political sovereign subject. It would therefore be within legality to find appropriate ways to carry out the exercise of the right to decide, while at the same time it finds its justification in the realm of facts, both historical and present, when we see the tremendous popular and parliamentary support that the defence of this right has aroused. As we can see, the fundamental difficulties of the Report are present from the beginning, in that the way of facts, a specific political will, seems to prevail over the normative question, that is, over the grounds that legitimize or not that will. 
Thus, the Report began its career wondering what pathways the legal system offers or might offer in order that the people of Catalonia may satisfy the right to decide about their collective future. To do so, the Institute draws on the constitutional principles which in its opinion would guide the selection, interpretation and application of the constitutional and legal norms relating to the procedures for the referendum. The application of the principles is justified by the difficulty of the problem. These principles are twofold, and also have a certain order of priority, but eventually, first, the principle of the rule of law will be altered, and secondly, the democratic principle. Both are contained in Article 1.1 of the Spanish Constitution that states that "Spain constitutes itself a social and democratic state of law". It is just on these principles and the interpretation of them where we will find the way the Institute seeks to solve the contradiction into which the Resolution had fallen, and the grounds on which it can build its defence of a factual conception of political power over one with a normative conception.

The first difficulty we would have to face would be to try to figure out how the two principles are enshrined in the Constitution, since it is not clear whether one would think that they are really two independent principles or they maintain a certain relationship of dependence between them, to the extent that one could think that they are one single principle. At first glance it may seem that the Constitution does not speak of two independent principles, since it does not define the country as a democratic state and with a rule of law, but rather as principles that maintain a close connection between them, to the point that they can only be conceived of as intertwining principles, which is what appears from the wording of the Constitution when it speaks of a democratic state of law. If this was so, and that is my opinion, a contrary position would have to be maintained against what is argued in the Report. This chooses to consider them as two separate principles. It does this by beginning to analyze what would be the consequences of the principle of the rule of law, the fulfillment of which necessarily requires acting within the existing law.

This principle implies, on the one hand, "Submission of power to a law emanated democratically which imposes limits to power" (p. 9) and on the other, "respect for legality without doubt reinforces the whole political and democratic legitimacy of the process of consultation" (p. 9). In these statements there are several issues that deserve our attention:

1) The right emanates democratically, that is, the right emanates from the people. A right that is qualified as democratic can only come from the people.

2) Public power must be submitted to that law, which is what establishes the limits of that power.

3) In consequence, respect for legality would strengthen the political and democratic legitimacy of the consultation process.

In my opinion, the central question is in the first and third points, stating that the law comes from the people and, consequently, that compliance reinforces political and democratic legitimacy. According to what is said in the Report, the core of the argument is not in the law but in the people, from whom law emanates. Hence, public powers have to act according to the law established by the people, which would be the only means at its disposal to achieve its democratic legitimacy. In a democratic system, these statements should be evident, as in the nature of democracy law has to come from the people, just as power has to adjust its behaviour to the requirements of that law. Unless we have clear what is understood by the people, or at least how we could conceive of the people differently from how it is thought of in the Report, since it is possible is to understand the people not only in this sense, as an effective political will of a natural being, but also as the rational political will of a moral being. Hence it would follow that if in the first case, law emanates from the people, in the second, the people is a legalrational construct subject to that very law. Ultimately there are two conceptions of what could be understood by the people. One is to understand it as a factual reality, a constituent subject, from whom law emanates; the other considers the people as a normative reality, a constituted subject, so necessarily in the same terrain as law, which emanates from that reality, being itself law.

If this could be maintained, then the principle of the rule of law could be though of in two ways. According to the first, we would understand that this principle would require that the powers be submitted to the law emanating from the people, from the democratic political will, which would be located in the realm of facts. This first interpretation would mean that the principle of the rule of law would be subordinated to the democratic principle. However, if the people are conceived of not as a factual political will, but normative, that is, if the people are thought of as a body politic created in a legal shape subject to the requirement to act within the limits established by law itself, then we have to consider the principle of the rule of law not as subordinate to the democratic principle, but we would have to conceive of both as intertwined, that neither could prevail over the other. Habermas 
[6] admits the difference between the democratic principle and the principle of the rule of law since there may be situations where one exists without the other, that is, there may exist the principle of the rule of law without the democratic principle, to the extent that a regime subject to law is possible without it necessarily being democratic, but it could not be a democracy without being immersed in law, which in a democratic system could not think of two separate principles, but in the joint articulation of both.

The second principle spoken of in the Report is the democratic principle, which should be understood as a principle whose light should be

To interpret existing legal precepts, not as a legitimating principle of hypothetical alternatives in case the legal ways are insufficient to channel the claims described above. It is not a question of a principle of alternative application to the principle of the rule of law. What is being advocated here is the application of the principle of democracy as complementary to the principle of the rule of law (p. 10).

That is, a principle that is not an alternative to the principle of the rule of law, but complementary to it, which would give the "the greatest expansion possible to the constitutional right to citizens' political participation under Article 23 of the Constitution" (p. 9). Thus begins its reflection on the democratic principle, a reflection that seems apparently consistent with the argument we are making. However, this line of reasoning is itself abandoned immediately, just at the point where the Report is supported by the Canadian Supreme Court decision of 1998, in which it was argued that according to the democratic principle if a province agreed its separation from the Federation, then the latter would be required to negotiate the terms of separation. It seems evident that if the democratic principle serves to legitimize the result of a consultation, then it is clear that on that basis it would also justify holding it, for if that principle serves to legitimize the most important aspect, namely, the start of talks to bring about the separation process, it must also serve to justify the least important, that is the holding of the consultation.

From all this we may conclude that the democratic principle has enormous potential, in that it can be understood not only in a restrictive sense, intertwined with the principle of the rule of law and therefore limited to interpreting the legal system according to which we could deduce what the general will would want, that is, the sovereign, just as it is defined by the constitutional order itself. However, it would also be possible to understand it as original and predominant over any other principle. The Report proposes "to interpret the precepts in force in the light of the demands of the democratic principle” (p. 12), with what appears to be a very gentle inclination in favour of granting a certain dominance to the democratic principle, which will be clearly revealed when it clashes with the possible refusal of the State.

According to the Report, "The State can only refuse the consultation if indisputable constitutional objections could be made to it" (p. 13). Therefore it proposes five ways that would enable the consultation to be implemented, so that if the state refused to convene or allow it "it would place the issue in the purely political sphere and open up to the Generalitat the possibility of legitimately using alternative ways of announcing the consultation" (p. 13). This means that if the state denied the possibility of holding the consultation, the solution to the problem would be located not in the legal field, but in the political, that is, outside the law. The argument is confusing because it is not easy to understand why the State would refuse to allow such a consultation, if the Constitutional Court, the body which represents the State, and which what would ultimately deny or affirm the constitutionality or unconstitutionality of such issues, deemed that convening the consultation was constitutional. But if the Court, in the face of the doubt raised by the relevant body of the state in its appeal, decided that it was not constitutional, how would it be possible to argue that the question is then in the political arena, outside the law? It gives the impression that the defence made in the Report of the two principles, the principle of the rule of law and the democratic principle, is a defence finally biased in favour of the democratic principle, understood moreover in factual terms, that is, as the expression of a majoritian political will.

This can be seen more clearly when it refers to "a political component of extraordinary power" (p. 14) that is possessed by "popular consultations regarding the political future of a particular political community that is part of a larger community" (pp. 13-14) which leads it to recognise

The modesty of the contribution that law can make in the channelling of the problem posed. Law has to accompany the political process as far as possible, but lawyers should be aware that, as history amply demonstrates, if the claims are politically "serious" and they do not find in the current system legal mechanisms to express themselves and to become effective, they usually end by opening up alternative routes 
through other legal frameworks or simple factual way, later legalized (p. 14).

Regardless of what is in the Report the democratic principle becomes relevant not only after holding the referendum, but also before, in order that it be convened; what we must note is that this Report does not defend the concordance of two principles, the rule of law and the democratic principle, but only one of them, namely the democratic principle, since the first of them, the principle of the rule of law, is based on that same democratic principle, to the extent that that the Report holds that law must come from a majoritarian political will, and thus the true principle is always the democratic one. Law emanating democratically from the people imposes limits on state power, but cannot impose any limits on the political will from which that law emanates. This is the reason why it has to be argued that the Report defends not two principles but only one, the principle that every norm and limit comes from a specific political will. Moreover, something more has to be said, that it defends not a single principle, the democratic, but actually it does not defend any principle, but only a rule, the majority rule, defending it from the standpoint of a naked political will, that is, particular, even though it is a very large particular. But the seriousness of political demands is never found in the numbers that support them, but the quality of the arguments that support them. Number is a necessity, but by itself insufficient. The first quality that a principle would demand, regardless of the support it may obtain, is its universality, that is, its moral quality, which can never be partial or the expression of a particular will, however large that majority may be.

\section{Two Conceptions of Sovereign Power}

The background to all this discussion responds to a difference between two conceptions of sovereign power, one factual and the other normative, because while the former allows the democratic principle pre-eminence over the principle of the rule of law, the second would require the intertwining of the two principles. Both traditions have survived to this day, so that we must distinguish them in order to clarify the terms in which we debate them. The factual conception of sovereign power stems from Hobbes, the second is seen in Spinoza, but gains its full reality with Rousseau and Hegel. To see it we would have to start from the basics of legal-political structure of the modern state, which are in the Hobbesian conception of power as absolute and unlimited power. From Hobbes' approaches emerge two lines of thought that challenge his ideas. The first arises from his own factual conception of power and is restricted to conceiving the need to establish certain limits on that power. In it Spinoza's ideas about the state as a limited political state will be found, as well as those of Bentham who conceived it as selflimited state. The second line breaks radically with Hobbes by thinking of power in normative terms and it can be traced not only in the work of Rousseau and Hegel, but also in Kant and the Federalist Papers.

For Hobbes, sovereign power is necessarily an absolute power, without limits, without any effective limits, not even moral limits, those that are determined by natural laws that our reason discovered cannot act as a brake since they only have viability within us, which leads him to set up sovereign power as a factual power, which is essential in the management of our relationships with others. We need not stop now to ponder whether his contractarian vision of the social order is accurate or misguided, not even in its original iusnaturalist basis, but only in the terms in which sovereign power is constituted as an absolute power and regardless of whether it is the power of one or an assembly. For him, sovereign power is constituted without limit, to the extent we give up our rights in order that the power that we constitute and which we hand over keeps us in what matters most, the defence of our lives. But it goes even beyond that, because what has been instituted is a power that escapes the possibility of control, an unrestrained power. In order to leave the state of nature we constitute an absolute power over us that can do everything, while we become its subjects. Once instituted the subjects can claim and do nothing. We have created an absolute power such that it cannot be confined unless we generate a power greater than that absolute power that we seek to control. A factual power has been instituted that would only be limited by an even greater power, a power that cannot be that that of a superior being -veritas- because Hobbes does not admit the separation between religion and politics as he defends the original political unity. Thus, only the power that comes from auctoritas can constitute its limit, although this might not be possible since auctoritas could not be set against potestas, for in Hobbes there is no valid distinction between the two, in that summa potestas has been transformed into summa auctoritas [7]. Hence that power capable of limiting the sovereign power can only be understood as the power of a will even more powerful than the will to power that we want to limit. This is the paradox in which Hobbes encloses the legal-political thought in trying to get us out of the situation of permanent war in which men find themselves in the state of nature, to bring us into a state of perpetual war, for only through the use of a force greater than that possessed by the established powers can we 
can bring them down. From that moment, the first task that legal and political thought has to face is to try to legitimize the limitation of power; then it will have to try to conceive of it in a radically different way.

The latter is what Rousseau will do when he considers in the Social Contract that the founding moment of a society is the social contract, that "act by which a people is a people" [8], For this "act ... that is the true foundation of society" the act by which a people as a natural being, ruled by feelings of identity and belonging, is transformed into a people as a moral being, in which a common ground is established which enables different feelings to coexist, but whose conflicts are resolved in reason. This was to be understood as the moment in which the people as the constituent power metamorphosed into the constituted power, or to put another way, the "act of association" that "creates a moral and collective body" [9]. Rousseau institutes the general will on the unanimous agreement or will of the many, that is, the political will, but with the proviso that the general will is settled, at the same time, on three conditions, the fulfilment of which grants it legitimacy: in it, it has to attain the protection of life and possessions of all its partners; each of its members shall obey himself alone and, finally, everyone will remain as free as before. Regarding the first point, Hegel turns it around, starting not from a political will, but addresses the issue from a philosophical perspective beginning with the supposition of the idea of the universal— to itself-although to ascertain immediately its existence - in the particular wills - to itselfthrough those who would again reach the universal, now in the state-in itself and to itself. Thus far what he does is to avoid the problems of founding a political regime arising from the particular will [10], since in the return to the universal which is the state, the particular will know itself in it and contemplates itself in the universal. In this way, Hegel makes it possible for a history, that of the revolution itself rooted in the original act, to end. After him, rationality would be fully reflected in the construction of the rational state, so it will be virtually impossible to justify any revolutionary alteration of a legal-political rational order.

As against Hegel, it has to be recognized that the starting point for Rousseau is wrong, even if, generally speaking, the conclusions to which he comes do not stem from that point. He tries to base a social order in the general will, but not by drowning the particular will, perhaps because he did not know how to prevent it. Hence he lets this will play in three stages, although in the first two of them, it is not with his agreement. First, the particular will appears in the act of origin, because when faced with the problem of unanimity, he has no choice but to give entrance to the will of the many. This does not mean that the particular will was not also unanimity, but its emergence is even clearer when it appears in the will of the many.

Secondly, it reappears in the same exercise of the general will, which has to be conducted by the people meeting in an assembly in order to give themselves the law. The people in the assembly have necessarily to decide according to the majority principle, which would establish the general will, according to Rousseau. In his opinion, the reason would be that when one votes one does not express agreement or disagreement with the proposition, but if it is in accordance with the general will then it is his own will. Therefore, the declaration of the general will could be obtained from the calculation of votes. His argument rests on the assumption that it is possible to identify the will of each one with the general will, but we must admit that, as Hegel said, one thing is that the universal can only be realized by means of the particular and the other is Rousseau's contention when he argues that the particular will is identified with the general. This error is accompanied by another in that it considers the law as an expression of the general will, when it should have been characterized it as making that will a clarification of it, that is, as a particularization of it.

Finally, Rousseau fully admits the play of the particular will when considering the election of the government, an act that by its nature he considers particular. This is the reason why the general will cannot act, which can only be done in relation to general issues, so that people as the general will cannot decide its government, unless the people themselves were the government, that is, a democracy, which then, as a government, could act particularly and choose their rulers. The solution to the problem that Rousseau gives is fundamental because it opens the field within the legal-political order to establish a full-fledged representative democracy. All that was needed was to broaden Rousseau's conception of democracy and understand it not only as the appropriate way to elect our leaders, whose activity will be to enforce the law-the executive power-but also our representatives, responsible for making the law — the legislature—a law that should now be understood as a direct expression of the will of the majority of our representatives, at the same time as an indirect expression of the general will.

In a way, Hegel had anticipated this by stating that making law is already an accomplishment [11], which leads, in a State based on freedom, that "many wills of individuals also desire to have a share in political decisions" (p. 408) while he argued that the people should determine the content for which the government was necessary in order to restrict its arbitrary power. However, Hegel ends by leaving this position to try to solve the 
problems of the legal-political order from a scientific and not political perspective, which led him to relativize the importance of popular participation in the determination of the common good, to conclude that it is a matter of knowledge rather than participation.

However, Hegel ought to have understood the potential of Rousseau's proposal on the conversion of the people into a democratic government in order to choose, in turn, the authority charged with government, so that he could have repeated the foundation model of the legal-political order, the universal that is determined in the particular, from which it returns to that through the institutionalization of the state, but now in the instituted State. The only difficulty that he would have faced was to bear in mind that it was necessary to alter the order of the factors, because in this second level one cannot start from the universal but from the particular, of the sum of the will of the many or the majority principle. Nevertheless, this does not alter the result, for those particular wills are expressed now in the State, which are still a determination of the universal and not an expression of a wild will without any subjection. Moreover, in this legal-political order a measure of control can be established that ensures the subjugation of the decisions adopted in the public interest. It would be, therefore, to institutionalize a mechanism ruled by judgment [12], which would deal with restoring the general or popular sovereignty, when necessary and by using the appropriate procedures against the force that the will of the many could represent. In this case as we see, the first moment at this second level would not be that of the universal, but rather that of the particular will, although always within the State's rational order, the second, characteristic of the particular will, would now be the rationale of the State, which would occupy the judgment of the courts, and the third, the universal in and for itself, would be the general interest or interest of the State. Thus, Hegel would not just have provided the end of history as revolutionary history, but could have defended that it was the beginning of another, in which the legitimacy of the revolution would not fit, but rather the justification for the changes settled on the exercise of the power of a majority principle bridled by judgment both of the courts and of public opinion educated in its inner will, that is, a public opinion with a moral conscience [13].

\section{Conclusions}

The Report supports itself on a factual conception of power, according to which a majoritarian political will must have the capacity to decide. The first problem we have to address is not so much the fact that this political will decides, as to whether from it the right to decide can be obtained. According to a factual conception of power, law is created by the political will that possesses enough power to implement a particular legal and political configuration, but this conception leads to the resolution of conflicts ultimately depending on who has enough strength to impose itself. A normative conception of power would not make law depend simply on the political will, but would start from the need for this right to be rationalized through its transformation into a moral being, on which that law might now depend, to the extent that that same will is subject to it. To put it another way, according to this conception uniquely in the legal order I have the right to decide, only in the sovereign do I possess this right, because only in him do I have civil liberty, apart from this sovereign I do not have the right, I possess only natural liberty and of course, the power to impose my will. Thus, I would only have the right to decide if I belonged to the sovereign, that is, I was a member of it, although I could always decide if the force were with me, regardless of that legal order. Once this is admitted, one might wonder, in the case that I did not have this right would there be reasons that supported the need for such recognition? We can, therefore, place the debate in the realm of facts, in which there is no place for the resolution of conflicts in rational terms, or by legal means, which would gives us the common ground, in which a reasonable solution to conflicts is possible.

However, we can speak of the right to decide as the right to participate, just as it is recognized in our constitutional order, which might be understood as the right to give oneself the norm, normative autonomy, but also as self-determination, albeit understood as a self-determination within the legal system itself. Secondly, one could speak of the decision outside the law, which would lead us to approach it from two perspectives, one normative and the other purely factual. The former would be based on consistent rational arguments, which would be supported in the absence of the questioned state in matters of individual rights and liberties, as well as collective rights relating to language and culture. These would be the only reasons that would support the claim of the right to decide outside the legal system, based on the legitimizing weakness of that same order, or in other words, only conditions of oppression would morally justify rebellion. The second approach would address a situation in which those rights, individual and collective, are respected. In this case there would be no justification for any right to decide outside the law, that is, there would not be a right to decide apart from the right of participation 
recognized by the Constitution.

Now this does not avoid the problem. It would only point out that the conflict would cease to be raised in the normative terrain, to the extent that there is no room for its resolution either in law or in morality, so it can only fit within the realm of facts. This is the situation when it should appeal to the Canadian solution, but not because there is a democratic principle to support it, there is no principle that could do that, but because there is a confrontation to which for the first time in our history we should not give a fratricidal solution, but a rational one. We should be able to achieve a peaceful and reasonable outcome for what is nothing but a peaceful, though irrational, claim, because it is particular, which could bring us to the "abyss of an all-destroying barbarism" [14].

\section{References}

[1] Rubio Llorente, F. (2012) Un Referéndum Para Cataluña. El País.

[2] Ferreres, V. (2012) www.iconnectblog.com/2012/11

[3] See Scotland Analysis (2013) Devolution and the Implications of Scottish Independence, February 2013, in which we see in its annex, on which the report is largely built, all reflection revolves around the Treaty of Union, 1707, from which some conclusions are obtained: The union was made freely by Scotland and England and this led to the dissolution of Scotland as a state, so there can be no reversion. And that Treaty does not currently sound as a treaty in international law. These statements enable them to conclude that the rest of the UK will continue to exercise the existing powers of the United Kingdom itself, Scotland being born as a new state, with all the disadvantages that such birth entails, especially initiating its incorporation into the European Union.

[4] Habermas, J. (1996) Between Facts and Norms. Contribution to a Discourse Theory of Law and Democracy. Trans. by Rehg, W., The MIT Press, Cambridge, 455.

[5] Instituto de Estudios Autonómicos (2013) Informe sobre los procedimientos legales a través de los que los ciudadanos y las ciudadanas de Catalunya pueden ser consultados sobre su futuro político colectivo, Barcelona.

[6] Habermas, J. (1996) The Inclusion of the Other, Studies in Political Theory. In: Cronin, C. and De Greiff, P., Eds., The MIT Press, Cambridge, 253 and ff.

[7] Schmitt, C. $(1996,1938)$ The Leviathan in the State Theory of Thomas Hobbes. Meaning and Failure of a Political Symbol. Trans. Schwab, G. and Hilfstein, E., Greenwood Press, London, 44-45.

[8] Rousseau, J.J. (1762) The Social Contract. Trans. by Cole, G.D.H. In: The Public Domain, Book 1, 5.

[9] Rousseau (1762) The Social Contract. Trans. by Cole, G.D.H. In: The Public Domain, Book 1, 6.

[10] Habermas, J. (1996) The Inclusion of the Other, Studies in Political Theory. In: Cronin, C. and De Greiff, P., Eds., The MIT Press, Cambridge, 15.

[11] Hegel, G.W.F. (1894, 1830) Lectures on the Philosophy of History. Trans. Sibree, J., Kessinger Legacy Reprints, 408.

[12] A. Hamilton, (1982, 1787-8) The Federalist Papers. With an Introduction and Commentary by G. Wills, Bantam Classic, New York, No.78, 472.

[13] In this respect, see Rawls' refelections on the vote in a constitutional democracy in Rawls (1993) Political Liberalism. Columbia University Press, New York, 241.

[14] Kant, I. (1781, 1787) Critique of Pure Reason. Trans. by Meiklejohn, J.M.D., Project Gutenberg eBook. www.gutenberg.org 